\title{
Empathic orientation among medical students from three universities in Barranquilla, Colombia and one university in the Dominican Republic
}

\author{
Victor Patricio Diaz Narváez, M.D., ${ }^{a}$ Luz Marina Alonso Palacio, M.D., ${ }^{b}$ \\ Sara Elvira Caro, Magister, ${ }^{b}$ María Guadalupe Silva, M.D.,' Joel Arboleda Castillo, \\ Magister, ${ }^{c} J o r g e ~ L u i s ~ B i l b a o, M . D .,{ }^{d}$ and Jesús Iglesias Acosta, M.D.
}

\begin{abstract}
Objective. To compare empathic orientation among medical students from three schools of medicine in Colombia and one in the Dominican Republic.

Material and Methods. Empathic orientation of medical students was measured using the Jefferson Scale of Physician Empathy (JSPE), Spanish version for students (the "S" version) validated in Mexico and Chile, and culturally adapted to Colombia and the Dominican Republic. Data were compared using a threefactor analysis of variance (model III) and a discriminant analysis.

Results. No differences in empathic orientation were observed among courses and between sexes, but differences were found in schools of medicine considered as a unit in each studied country. Conclusions. Empathic orientation levels tend to reduce as courses advance. This was observed in both male and female students and in all schools analyzed.

Key words: empathy; Jefferson Scale of Physician Empathy (JSPE); empathic orientation; empathy components.
\end{abstract}

http:/ /dx.doi.org/10.5546/aap.2014.eng.41

\section{INTRODUCTION}

Hojat, et al. ${ }^{1}$ propose that empathy is such a wide concept that it can bear different definitions, approaches and theories. ${ }^{1,2}$ Thus, it can be regarded as: a) cognitive $e^{3,4}$ or b) cognitive and emotional, if emotional intelligence is included in the analysis. 5,6 The capability to understand other person's experience and feelings, and the ability to observe and understand the world from the perspective of the other are related to the cognitive component; 7 in turn, the affective aspect is related to the aptitude to join the experience of others. ${ }^{7,8}$ Some studies have demonstrated that the presence of empathy in physicians allows to develop a better patient care because:

a) it improves satisfaction, ${ }^{9}$

b) it increases indulgency, ${ }^{10}$

c) it enhances the doctor's ability for diagnosis and treatment, ${ }^{11}$ and

d) it significantly reduces the risk of malpractice claims ${ }^{12}$ and is cross curricular to all specialties.

A positive doctor-patient relationship substantially increases the chances of healing and thus becomes a critical element of medical practice. ${ }^{13,14}$ The growing intervention of technology has caused certain effects: patients perceive a distance between them and their doctors. ${ }^{15}$ The empathic component is therefore significant for the training of medical students and, as a result, it should be included in the teaching-learning process. Empathy has been studied in Europe, the United States and England, among other countries, ${ }^{1-5}$ but as far as we know, there are no reports in the literature on how empathy works in medical students in the north of South America and the Caribbean, nor articles comparing medical schools from one or several different countries. Our objective was to evaluate and compare empathic orientation in medical students from four universities: three in the city of Barranquilla (Colombia) and one in the Dominican Republic.

\section{POPULATION AND METHODS}

This was an exploratory, non experimental, descriptive, crosssectional, ex post facto, cause-effect study conducted in accordance with the bioethics standards of the 
Declaration of Helsinki, and focused on student populations from first through fifth year of the Medicine Degree of the School of Medicine of Universidad del Norte, Universidad San Martín and Universidad Libre, located in the city of Barranquilla (Colombia), and of Universidad Central del Este, in the Dominican Republic. Data were collected over three weeks, from March $26^{\text {th }}$ to April $13^{\text {th }}, 2012$ almost simultaneously at all schools (in both countries involved). The sample was made up of all subjects who were available for assessment on the corresponding day. At the time of administering the scale, all students were attending the last part of the first semester of each course. Participants in each sample were administered the Jefferson Scale of Physician Empathy (JSPE), Spanish version for students (the " $\mathrm{S}$ " version), validated in Mexico and Chile, ${ }^{2,13,15}$ and culturally adapted to Colombia and the Dominican Republic as per the judges' criterion (a committee of judges especially assigned in Barranquilla, Colombia, and the Dominican Republic). No exclusion criteria were applied since the objective of this study was to assess the outcome measure in the largest number of students possible. In agreement with what has been described above, a single anonymous and confidential measurement was performed, using a neutral operator, in the classrooms of first through fourth year students. In the case of fifth year students, the scale was administered during a visit to the medical facilities with the same indications stated before.

\section{Statistical analysis}

Sums of scores corresponding to primary data obtained with the JSPE were initially evaluated with the Shapiro-Wilk's test for normality, and the three studied factors (university, course and gender) were assessed with Leveneen's homoscedasticity test. ${ }^{16,17}$ Descriptive statistics were estimated, with arithmetic mean and standard deviation of all factors and their corresponding levels. Mean values within the main studied factors (university, course and gender) were compared using a general, threefactor, univariate linear model (ANOVA), model III, and a multiple Duncan comparison test for unbalanced data, as per Díaz. ${ }^{18}$ The observed power $(1-\beta)$ and the effect size were examined. ${ }^{18,19}$ Estimated statistics were plotted in a single arithmetic diagram. Subsequently, a discriminant analysis was performed on the basis of the values obtained for each JSPE answer taken altogether as independent outcome measures. Wilks' $\lambda$ statistics were used. ${ }^{20}$ Box's $M$ test was employed to check if each university's (school of medicine) variance and covariance matrices were originating or not from a single population. ${ }^{21}$ Eigenvalues ${ }^{17}$ and canonical correlation were estimated. ${ }^{20}$ Each group centroids were represented in plots. Lastly, the percentage of data correctly classified by university and by the overall analysis was weighed. Data were processed with the SPSS 20.0 statistical software. The significance level was established at $\alpha \leq 0.05$ and $\beta \leq 0.05$ in all cases.

\section{RESULTS}

Participants were students from the School of Medicine of Universidad del Norte $(n=345 / 859 ; 40.16 \%)$, Universidad San Martín $(n=283 / 493 ; 57.4 \%)$ and Universidad Libre $(n=695 / 1129 ; 61.56 \%)$, in the city of Barranquilla (Colombia), and Universidad Central del Este $(n=515 / 853 ; 60.38 \%)$, in the Dominican Republic. No students refused to answer the survey. Table 1 shows the three-factor model results. The factors "university", "gender" and the interaction between "university" (school of medicine) and "course" (year) were highly significant $(p=0.005)$. However, the $\eta^{2}$ statistics, which indicates the effect size of the studied "treatment," was small. The test power was in all cases above the minimum admissible value: 0.95 (overall, 0.99). This shows that the effects of indicated factors and their interaction are small, but there is no risk of a type II error. As a result, any difference or similarity described should be examined cautiously because they exist but their magnitude is small $\left(R^{2}=0.069\right)$. Tables 2 and 3 present the mean values corresponding to the studied universities and courses, together with Duncan's test. Empathy levels were higher in the Universidad Libre and in the Universidad del Norte, and lower in the Universidad de San Martín, followed by Universidad Central del Este. Table 4 shows the results of the Duncan's test for courses. It was observed that empathy values reduced as courses advanced, and this occurred in both male and female students from all studied schools (Figures 1 and 2). The findings of Wilks' statistics, Box's M test, eigenvalues and canonical regression, and $\chi^{2}$ test enable the reliable implementation of a discriminant analysis to compare the entire matrices of scale answers. Figure 3 shows the centroids of each studied university. This figure demonstrates that the 
Universidad Central del Este in the Dominican Republic stands out and is different from the universities in Barranquilla, Colombia. Finally, Table 5 displays the results of the classification obtained with the discriminant analysis of subjects in studied groups (universities).
Classification was adequate in $20 \%$ of students from the Universidad del Norte, while it was $12.7 \%$ in Universidad San Martín, $81.3 \%$ in Universidad Libre, and $88.3 \%$ in Universidad Central del Este. Overall, the model was capable of a $61.2 \%$ adequate classification.

TABLE 1. Results of the use of the chosen model to compare the means of studied factors

\begin{tabular}{|c|c|c|c|c|c|c|c|}
\hline Origin & $\begin{array}{c}\text { sums of squares } \\
\text { Type III }\end{array}$ & gl & $\begin{array}{l}\text { Mean } \\
\text { square }\end{array}$ & $\mathbf{F}$ & Sig. & $\begin{array}{c}\text { Partial } \\
\text { Eta-squared }\end{array}$ & $\begin{array}{c}\text { Observed } \\
\text { power }^{\mathrm{b}}\end{array}$ \\
\hline Adjusted model & $34514.078 \mathrm{a}$ & 39 & 884.976 & 4.468 & 0.000 & 0.088 & 1.000 \\
\hline University & 4664.174 & 3 & 1554.725 & 7.850 & 0.000 & 0.013 & 0.990 \\
\hline Course & 1681.534 & 4 & 420.383 & 2.122 & 0.076 & 0.005 & 0.633 \\
\hline Gender & 4580.059 & 1 & 4580.059 & 23.125 & 0.000 & 0.013 & 0.998 \\
\hline University * Course & 8660.875 & 12 & 721.740 & 3.644 & 0.000 & 0.024 & 0.999 \\
\hline University * Gender & 352.875 & 3 & 117.625 & 0.594 & 0.619 & 0.001 & 0.175 \\
\hline Course * Gender & 1792.010 & 4 & 448.003 & 2.262 & 0.060 & 0.005 & 0.665 \\
\hline University ${ }^{*}$ Course ${ }^{*}$ & 2356.093 & 12 & 196.341 & 0.991 & 0.455 & 0.007 & 0.593 \\
\hline \multicolumn{8}{|l|}{ Gender } \\
\hline Error & 356113.145 & 1798 & 198.061 & & & & \\
\hline Total & $2.080 \mathrm{E} 7$ & 1838 & & & & & \\
\hline Total adjusted & 390627.223 & 1837 & & & & & \\
\hline
\end{tabular}

a. Square $\mathrm{R}=0.088$ (Adjusted square $\mathrm{R}=0.069$ )

b. Estimated with alpha $=0.05$

TABLE 2. Results of mean and standard error estimates corresponding to sums of scores in each studied university and course

\begin{tabular}{|c|c|c|c|c|c|}
\hline \multirow[t]{2}{*}{ University } & \multirow[t]{2}{*}{ Courses } & \multirow[t]{2}{*}{ Mean } & \multirow[t]{2}{*}{ Standard error } & \multicolumn{2}{|c|}{$95 \%$ confidence interval } \\
\hline & & & & Lower limit & Upper limit \\
\hline \multirow{5}{*}{$\begin{array}{l}\text { Universidad } \\
\text { del Norte }\end{array}$} & First year & 105.530 & 1.317 & 103.247 & 108.413 \\
\hline & Second year & 107.534 & 1.643 & 104.312 & 110.755 \\
\hline & Third year & 105.767 & 4.233 & 97.464 & 114.069 \\
\hline & Fourth year & 110.711 & 2.199 & 106.399 & 115.023 \\
\hline & Fifth year & 106.100 & 2.360 & 101.471 & 110.729 \\
\hline \multirow{5}{*}{$\begin{array}{l}\text { Universidad } \\
\text { Libre }\end{array}$} & First year & 109.351 & 0.853 & 107.678 & 111.024 \\
\hline & Second year & 108.800 & 0.980 & 106.879 & 110.722 \\
\hline & Third year & 101.211 & 2.314 & 96.671 & 105.750 \\
\hline & Fourth year & 102.129 & 1.343 & 99.495 & 104.763 \\
\hline & Fifth year & 101.964 & 2.452 & 97.155 & 106.773 \\
\hline Universidad & First year & 98.200 & 3.634 & 91.073 & 105.327 \\
\hline \multirow[t]{4}{*}{ San Martín } & Second year & 106.301 & 1.545 & 103.271 & 109.331 \\
\hline & Third year & 99.859 & 2.005 & 95.926 & 103.792 \\
\hline & Fourth year & 104.553 & 1.661 & 101.295 & 107.811 \\
\hline & Fifth year & 102.340 & 1.906 & 98.603 & 106.077 \\
\hline Universidad & First year & 100.937 & 1.436 & 98.120 & 103.755 \\
\hline \multirow[t]{4}{*}{ Central del Este } & Second year & 99.490 & 1.154 & 97.226 & 101.754 \\
\hline & Third year & 101.843 & 1.444 & 99.012 & 104.675 \\
\hline & Fourth year & 103.213 & 1.473 & 100.324 & 106.102 \\
\hline & Fifth year & 101.604 & 1.962 & 97.757 & 105.451 \\
\hline
\end{tabular}




\section{DISCUSSION}

In general, results of empathic orientation in medical students from the studied universities showed differences, but these were small. This is not the case of medical students in Mexico ${ }^{13}$ and Chile. ${ }^{22}$ Scores obtained in women were different from those obtained in men; this is consistent with other investigations conducted in medical students and residents ${ }^{13,23}$ and in dental students, ${ }^{24}$ but contradictory to other studies that found no differences between male and female students from other life science degrees. $7,15,25-27$ However, background data indicate that women are more empathic than men; 22,28 therefore, future studies should focus on looking for the reasons for such conflicting results given that in theory men are different from women, even in their brain structure, ${ }^{29}$ and it is known that women are more receptive to emotional signs and so tend to provide emotional support and comprehension, thus contributing to reinforce empathic relationships. Men are inclined to offer rational solutions. ${ }^{23,30,31}$ Alcorta-Garza, et al. ${ }^{13}$ propose that additional evidence is needed to establish a relationship between empathy differences by sex and intrinsic factors (such as the parental investment evolutionary theory) or extrinsic factors (e.g., gender role expectations), which would imply a different attitude at the time of choosing a medical career and training.

There is not a uniform distribution of empathic orientation among the courses of all studied universities. These results are consistent with those observed in other studies that have shown a decrease of empathic orientation among dental and medical students as they advance in their degree, ${ }^{25}$ but they are contradictory to those observed in the United Kingdom by Tavakol, Denning and Tavakol. ${ }^{32}$ Such conflicting findings regarding differences between sexes, among universities and courses point to the presence of other, not necessarily psychological, factors that may influence empathic orientation levels. In this sense, it is possible to suggest that such unknown factors could be associated with sociological processes that impact on empathy. This is evident in the differences found among universities based on the discriminant analysis.

In relation to the latter concept, we could mention again the advantages posed by empathic

TABLE 3. Results of a multiple comparison of Duncan means corresponding to sums of scores observed for each studied university

\begin{tabular}{|c|c|c|c|c|}
\hline \multirow[t]{2}{*}{ University } & \multirow[t]{2}{*}{$\mathbf{N}$} & \multicolumn{3}{|c|}{ Subset } \\
\hline & & 1 & 2 & 3 \\
\hline Universidad Central del Este & 515 & 101.6893 & & \\
\hline Universidad San Martín & 283 & & 103.8763 & \\
\hline Universidad del Norte & 345 & & & 107.5449 \\
\hline Universidad Libre & 695 & & & 107.6086 \\
\hline Sig. & & 1.000 & 1.000 & 0.948 \\
\hline
\end{tabular}

TABLE 4. Results of a multiple comparison of Duncan means corresponding to sums of scores observed for each studied course

\begin{tabular}{|c|c|c|c|c|}
\hline \multirow[t]{2}{*}{ Courses } & \multirow[t]{2}{*}{$\mathbf{N}$} & \multicolumn{3}{|c|}{ Subset } \\
\hline & & 1 & 2 & 3 \\
\hline Fifth year & 178 & 102.7640 & & \\
\hline Third year & 241 & 103.7718 & 103.7718 & \\
\hline Fourth year & 320 & 104.3750 & 104.3750 & \\
\hline Second year & 557 & & 105.8492 & 105.8492 \\
\hline First year & 542 & & & 107.0092 \\
\hline Sig. & & 0.186 & 0.086 & 0.311 \\
\hline
\end{tabular}


healthcare professionals for a better provision of care to patients, already described in the introduction. ${ }^{9-12}$ For this reason, the development of empathy in medical students through the teaching-learning process will have an influence in patient care and the quality of such care. However, some studies have questioned the possibility of modifying empathy through an education intervention, ${ }^{2,13}$ while other authors recognize that empathy can be learned and that the doctor-patient relationship, the medical possibility of helping to relieve pain, having helpful medical knowledge, and the doctor's hierarchical position over the patient, are all aspects that can be learned..$^{13,33}$

To date, the following are the factors known to influence on empathy:

a) perspective taking;

b) fantasy,

c) empathic concern;

d) personal discomfort. ${ }^{2,33}$
In addition, the connections among cognition, language, family experience and empathy imply a link between sensitivity to affective signs and the development of social cognition. ${ }^{33}$ All this demonstrates that empathy is related to social cognition, which is given by the individual's micro and macro systems, resulting in a dialectical relationship between them. This latter concept supports the presence of social factors, which were described in very general terms above. For example, "during the school years and adolescence, the school culture has an influence on students' empathic capabilities, with more opportunities to exercise empathic responsiveness in everyday life." ${ }^{33}$ In this regard, it has been proposed that "it is assumed that empathic sensitivity will probably favor altruism and restrain aggression, but a person's actual altruistic actions will depend on other determining factors, such as social inducers, limits imposed by the situation, potential costs, availability of the necessary

\section{Estimated marginal means of sums of scores in gender: female}

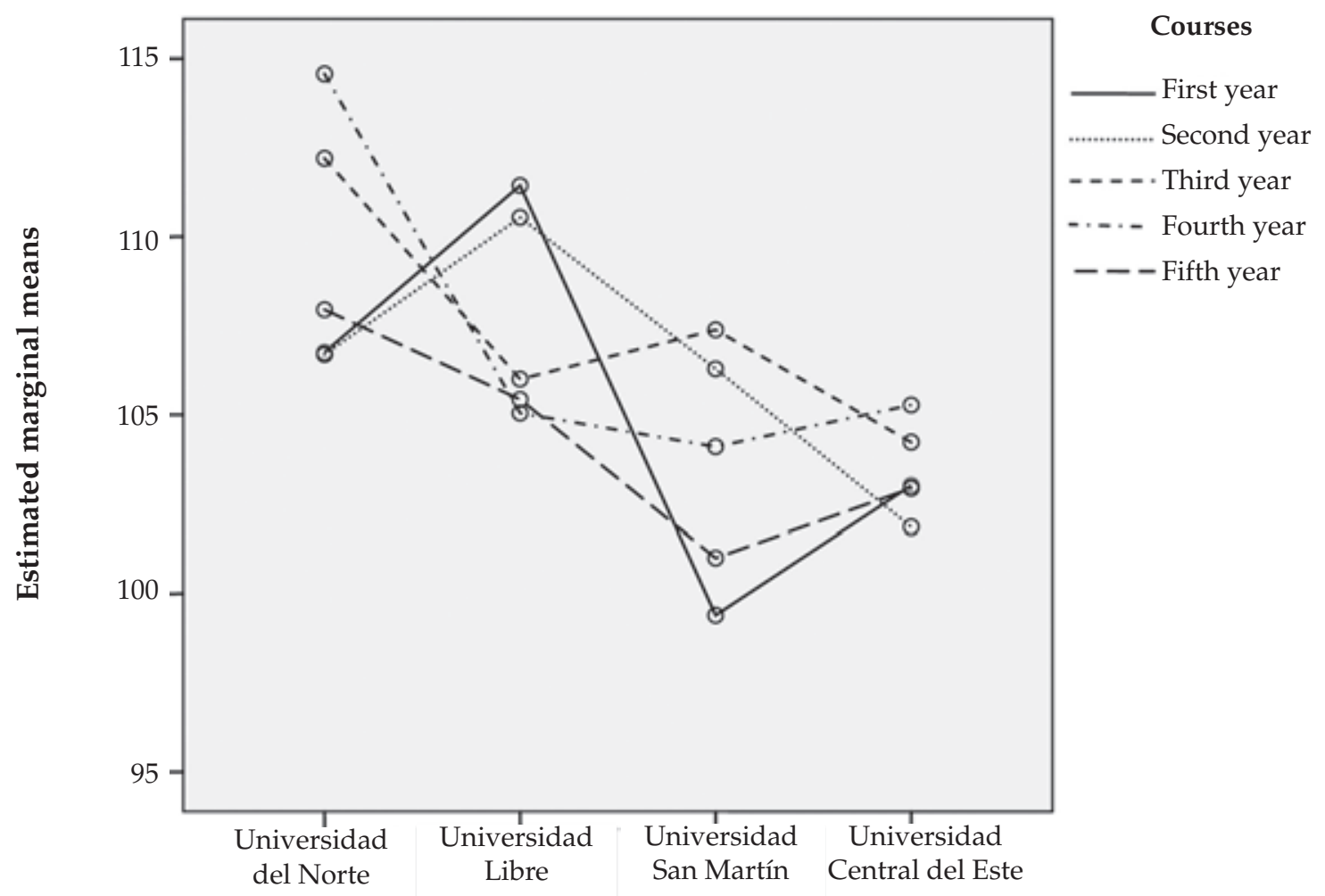

University 
FIGURE 2. Behavior profile of estimated means in universities and courses in male students

\section{Estimated marginal means of sum of scores in gender: male}

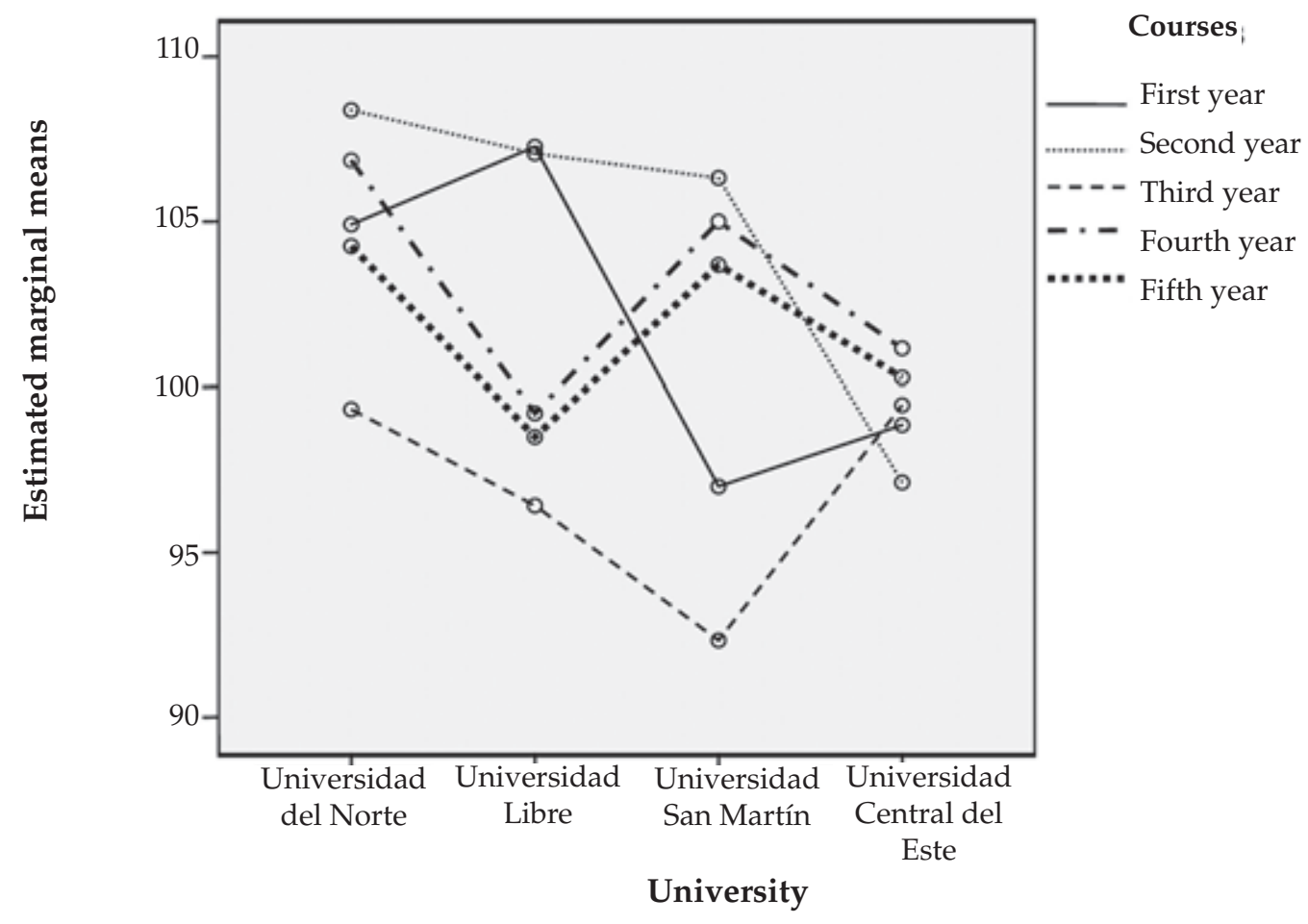

FIGURE 3. Group centroids (universities) and data dispersion around the corresponding centroid

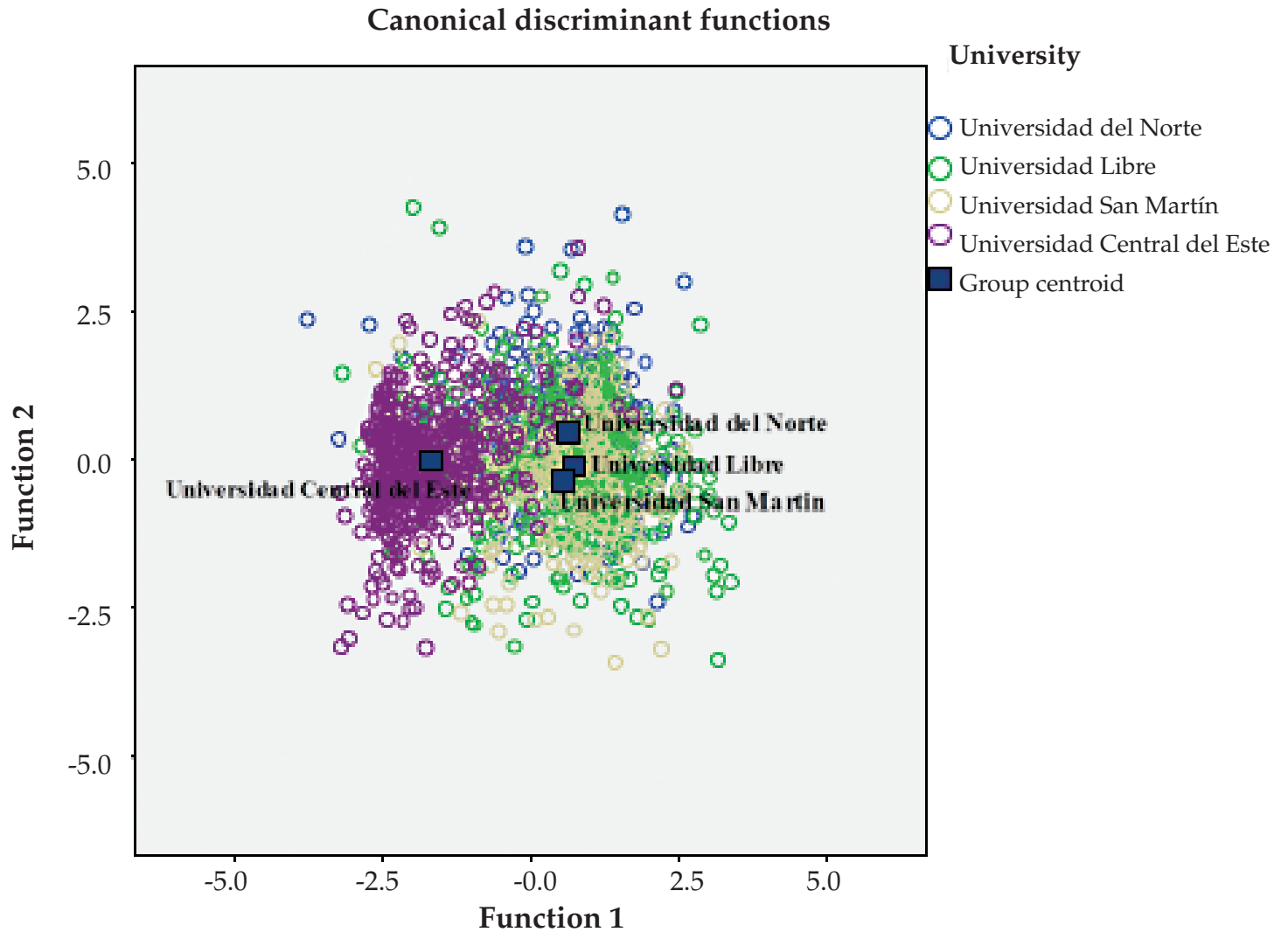


skills and resources to help other persons, vesting of responsibility, characteristics of the victim and his/ her relationship with the observer." 34 Therefore, these concepts indicate that "social cognition" is one of the factors with a direct influence on understanding empathy, ${ }^{35}$ which "includes emotion processing areas, social perception, knowledge on social rules, attributional style and the theory of mind." ${ }^{35}$ Consequently, we can infer that social cognition is critical to functioning within a community. Hence, empathy would make a direct contribution to such functioning.

Empathy is made up of cognition, emotion and self-regulation. ${ }^{34}$ Therefore, it could be stated that empathy is a basic form of social communication that can take place in varying social contexts and, as a result, requires the identification of emotional responses in other persons and involves welldefined abilities or competencies. ${ }^{6}$

The differences and similarities found in this study can be explained by the "impact" that social components can have on the empathy of medical students from the schools of the studied countries and would represent an empirical finding of how these factors influence on empathy. This could be the explanation for how "close results" were obtained from the schools in the same city and country compared to the "distant results" evidenced by a school in a different country, not with standing if sums of scores obtained with the JSPE were generally "low" in all studied schools. However, in this study it was not possible to answer the question "Which are the "specific" and "general" social components of empathy and how do they work?" In turn, the fact that empathy includes a social component allows to justify the theoretical trend towards suggesting that empathy may be related with abilities and competencies and, consequently, not only universities and, specifically, schools of medicine, are responsible for including such aspects in their syllabus because this is an issue that has to be approached at a family level and by all national education policies. However, this does not refer to the fact that the doctor-patient relationship should be seriously taken into consideration and included as a critical variable in the syllabus of schools of medicine in the context of the social responsibility that universities have toward the comprehensive training of professionals, taking advantage of the "biological" opportunity that students, are mostly young and their brains still offer windows of evolutionary opportunities. The results of this study support the prospect that empathy is "...an evasive concept, difficult to define and even more difficult to measure. The multiple dimensions of empathy and the inner properties of its components make it harder to comprehend through traditional study and research methods." ${ }^{2}$ Therefore, additional research is necessary to investigate how factors that make up empathy relate to one another in a particular manner and at a particular place, and the specific burden that each component has on the training of a medical student.

\section{Acknowledgements}

To the following Medical Doctors: Alberto Enrique D' Ottavio (School of Medicine, Universidad Nacional de Rosario, Argentina), Jaime Contreras (School of Medicine, Universidad Andrés Bello, Chile); Peter Mc Coll (School of Medicine, Universidad Andrés Bello, Chile), Hernán Borja Rebolledo (Director of the Medicine

TABLE 5. Results of subject classification in each university according to the statistical analysis model applied

\begin{tabular}{|c|c|c|c|c|c|c|c|}
\hline & & \multirow[b]{2}{*}{ University } & \multicolumn{5}{|c|}{ Predicted membership group } \\
\hline & & & $\begin{array}{c}\text { Universidad } \\
\text { del Norte }\end{array}$ & $\begin{array}{c}\text { Universidad } \\
\text { Libre }\end{array}$ & $\begin{array}{l}\text { Universidad } \\
\text { San Martín }\end{array}$ & $\begin{array}{c}\text { Universidad } \\
\text { Central del Este }\end{array}$ & Total \\
\hline \multirow{8}{*}{ 点 } & \multirow{4}{*}{$\vec{\Xi}$} & Universidad del Norte & 69 & 230 & 10 & 36 & 345 \\
\hline & & Universidad Libre & 27 & 565 & 20 & 83 & 695 \\
\hline & & Universidad San Martín & 18 & 187 & 36 & 42 & 283 \\
\hline & & Universidad Central del Este & 19 & 39 & 3 & 454 & 515 \\
\hline & \multirow{4}{*}{$\%$} & Universidad del Norte & 20.0 & 66.7 & 2.9 & 10.4 & 100.0 \\
\hline & & Universidad Libre & 3.9 & 81.3 & 2.9 & 11.9 & 100.0 \\
\hline & & Universidad San Martín & 6.4 & 66.1 & 12.7 & 14.8 & 100.0 \\
\hline & & Universidad Central del Este & 3.7 & 7.6 & 0.6 & 88.2 & 100.0 \\
\hline
\end{tabular}

a. Of originally grouped cases, $61.2 \%$ were adequately classified 
Degree, Universidad Andrés Bello, Viña del Mar); Mariano Grilli (School of Medicine, Universidad de La Plata, Mar del Plata Campus); Felix Díaz Rodríguez (School of Education, Universidad Federal de Bahía, Brasil), Claudio Flores Würth (School of Medicine, Universidad Austral de Chile), Verónica Hering (School of Medicine, Universidad Austral de Chile), Sara Herrera Leyton (School of Health Science, Universidad Católica del Maule, Chile), Gizaku Kuramochi (Universidad de la Frontera, Chile), Doris Carrasco Mardones (Universidad de Concepción, Chile), for their accurate suggestions, which were duly introduced in this article.

\section{REFERENCES}

1. Hojat M, Gonnella JS, Nasca TJ, Mangione S et al. Physician Empathy: Definition, Components, Measurement and Relationship to Gender and Specialty. Am J Psychiatry. 2002; 159(9):1563-1569.

2. Fernández-Pinto I, López-Pérez B, Márquez M. Empatía: teorías y aplicaciones en revisión. An Psicol. 2008; 24 (2): 284-298.

3. Sharmay-Tsoory SG, Tormer R, Goldsher D, Berger BD et al. Impairment in Cognitive and Affective Empathy in $\mathrm{Pa}-$ tiens with Brain Lesions: Anatomical and Cognitive Correlates. J Clin Exp Neuropsychol. 2004; 26 (8): 1113-1127.

4. Elliot R, Völlm B, Drury A, McKie S et al. Co-operation with another player in a financially rewarded guessing game activates regions implicated in theory of mind. Social Neurosc. 2006; 1 (3-4): 385-395.

5. Davis MH, Hull JG, Young RD, Warren GG. Emotional Reactions to Dramatic Film Stimuli: The Influence of Cognitive and Emotional Empathy. J Pers Soc Psichol. 1987; 52 (1): 126-133.

6. Fernández-BerrocalP,Extremera N. Emotional intelligence: A theoretical and empirical review of its first 15 year of history. Psicothema. 2006; 18:7-12.

7. Hojat M, Mangione S, Nasca TJ, Cohen MJM et al. The Jefferson Scale of Empathy: development and preliminary psychometric data. Educ Psychol Measur. 2001; 61(2): 346-365.

8. Gallangher HL,Frith CD. Functional imaging of "theory of mind". Trends Cogn Sci. 2003 Feb;7(2):77-83.

9. Beckman HB, Franckel RM. The effect of physician behaviour on the collection data. Ann Inter Med. 1984; 101(5): 692-696.

10. Falvo D, Tippy P. Communicating information to patients: patient satisfaction and adherence as associated with resident skill. J Fam Pract. 1998; 26 (6): 643-647.

11. Barsky AJ 3rd. Hidden reasons why some patients visit doctors. Ann Int Med. 1981; 94(4-1): 492-498.

12. Levinson W, Roter DL, Mullooly JP, Dull VT et al. Physician-patient communication: the relationship with malpractice claims among primary care physicians and surgeons. JAMA. 1997; 277(7): 553-559.

13. Alcorta-Garza A, González-Guerrero JF, Tavitas-Herrera SE, Rodríguez-Lara FJ et al. Validación de la Escala de Empatía Médica de Jefferson en Estudiantes de Medicina Mexicanos. Salud Ment. 2005; 28 (5): 57-63.

14. Mangione S, Kane GC, Caruso JW, Gonnella JS et al. Assessment of empathy in different years of internal medicine training. Med Teach. 2002; 24(4): 371-374.
15. Rojas AM, Castañeda Barthelemiez S, Parraguez-Infiesta RA. Orientación empática de los estudiantes de dos escuelas de kinesiología de Chile. Educ Méd.2009; 12 (2): 103-109.

16. Shapiro SS, Wilk MB. An Analysis of Variance Test for Normality (Complete Samples). Biometrika. 1965; 52 (3-4): 591-611.

17. Hair JF, Anderson RE, Tatham RL, Black WC. Análisis multivariante. Madrid: Prentice-Hall; 2001; 66-67.

18. Díaz-Narváez, VP. Metodología de la Investigación Científica y Bioestadística para Profesionales y Estudiantes de Ciencias Médicas. Santiago, Chile: RiLEditores; 2009;415441.

19. Frías MD, Llobell JP, García JF. Tamaño del efecto del tratamiento y significación estadística. Psicothema.2000;2(2):236240.

20. Levy JP, Varela J. Análisis Multivariante para las Ciencias Sociales. Madrid: Pearson Prentice Hall; 2003; 249-257.

21. Visauta B. Análisis estadístico con SPSS. Vol II.Madrid: McGraw-Hill; 1998;135-137.

22. Carvajal A, Miranda CI, Martinac T, García C et al. Análisis del nivel de empatía en un curso de quinto año de medicina, a través de una escala validada para este efecto. Rev Hosp Clín Univ Chile. 2004; 15 (4):302-306.

23. Hojat M, Gonella JS, Mangione S, Nasca TJ et al. Empathy in medical students as related to academic performance, clinical competence and gender. Med Educ. 2002; 36 (6): 522-527.

24. Sherman J, Cramer A. Measurement of Changes in Empathy During Dental School. J Dent Educ. 2005; 69 (3): 338345.

25. Hojat M, Mangione S, Nasca TJ, Rattner S et al. An empirical study of decline in empathy in medical school. Med Educ. 2004; 38:934-941.

26. Rivera I, Arratia R, Zamorano A, Díaz-Narváez VP. Evaluación del nivel de orientación empática en estudiantes de Odontología. Salud Uninorte, Barranquilla. 2011; 27 (1): 63-72.

27. Hojat M, Gonnella JS, Nasca TJ,Mangione S et al. The Jefferson scale of physician empathy: further psychometric data and difference by gender and speciality at item level. Acad Med. 2002; 77(10): 58-60.

28. Retuerto PA. Diferencias en empatía en función de las variables género y edad. Apuntes de Psicología. 2004; 22 (3): 323-39.

29. Baron-Cohen S. La gran diferencia: Cómo son realmente los cerebros de hombres mujeres. Barcelona: Amat; 2005; 15-24.

30. Hojat M, Gonella JS, XU G. Gender comparisons of young physicians' perceptions of their medical education, professional life, and practice: a follow up study of Jefferson Medical College graduates. Acad Med. 1995; 70:305-312.

31. IckesW.Gender differencesinempathicaccuracy:Differential ability or differential motivation? Methodology Meta Analysis, Social Perception and Cognition.2006. 7(1):95-109.

32. Tavacol S, Dennick R,Tavacol M. Empathy in UK medical y year and specialty interest. Education for Primary Care. 2011; 22: 297-303.

33. Almonte C, Montt MA. Psicopatología infantil y de la adolescencia. Santiago, Chile: $2^{\mathrm{a}}$ Ed. Mediterráneo;2012;45-58.

34. Mestre MV,Samper P,Frías MD. Procesos cognitivos y emocionales predictores de la conducta prosocial y agresiva: la empatía como factor modulador. Psicothema. 2002; 4 (2): 227-232.

35. Moya-Albiol L, Herrero N, Bernal MC.The neural bases of empathy. Rev Neurol. 2010;50(2): 89-100. 


\section{Anexo 1}

Estimado Estudiante:

La evaluación del paciente respecto de la calidad de la atención clínica está determinada por los conocimientos científicos y tecnológicos del profesional y por otros factores, entre ellos, la empatía.

Por lo anterior surge la necesidad de estudiar la empatía en los estudiantes de Medicina. Para ello estamos realizando la investigación denominada: "Medición del nivel de orientación empática en alumnos de Facultades o Carreras de Medicina".

Esta investigación NO perjudica a ningún estudiante.

Esta investigación SÍ tiene grandes beneficios para todos los estudiantes porque les permitirá contribuir significativa y directamente a la posibilidad de mejorar su curriculum o pensum. Por tanto, su contribución es decisiva.

Para este fin se les adjunta una encuesta que posee las siguientes características:

1. No debe escribir su nombre, esta es una encuesta confidencial.

2. Responda en forma individual.

3. Todas las respuestas son posibles. No existe preconcepción para responderlas.

4. No existen respuestas correctas o incorrectas, sino diferentes estilos de respuestas, por tanto cualquier respuesta es válida y aporta a la investigación.

5. Está en una escala de 1 a 7. En la encuesta se explica la valoración.

6. Si Ud. no entiende algún enunciado, pregunte al examinador.

7. Es necesario responder a todas las preguntas.

\section{Le damos las gracias por su contribución al desarrollo de la investigación.}

\section{ESCALA DE EMPATÍA MÉDICA DE JEFFERSON (VERSIÓN - S)}

Curso: $1^{\circ} \_2^{\circ} \_3^{\circ} \_4^{\circ} \_5^{\circ} \_$Género: $\mathrm{M} \_$F__ Edad

Indique si ha reprobado alguna asignatura: Sí__

Instrucciones: Indique su grado de acuerdo o desacuerdo con cada una de las siguientes afirmaciones encerrando en un círculo el número apropiado después de cada afirmación. Utilice la escala de 7 puntos (un mayor número indica un mayor acuerdo):

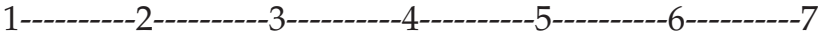

Totalmente en desacuerdo Totalmente de acuerdo

1. La comprensión que tenga el médico de los sentimientos del paciente y de su familia no influye en el tratamiento.

2. Los pacientes se sienten mejor cuando el médico comprende sus sentimientos.

$\begin{array}{lllllll}1 & 2 & 3 & 4 & 5 & 6 & 7 \\ 1 & 2 & 3 & 4 & 5 & 6 & 7 \\ 1 & 2 & 3 & 4 & 5 & 6 & 7 \\ 1 & 2 & 3 & 4 & 5 & 6 & 7 \\ 1 & 2 & 3 & 4 & 5 & 6 & 7\end{array}$

3. Es difícil para el médico ver las cosas desde la perspectiva de su paciente.

4. La comprensión del lenguaje corporal es tan importante como la comunicación verbal en la relación médico-paciente.

5. El buen sentido del humor del médico contribuye a tener un mejor resultado clínico. 
6. Debido a que la gente es diferente, es difícil ver las cosas desde el punto de vista del paciente.

$\begin{array}{lllllll}1 & 2 & 3 & 4 & 5 & 6 & 7 \\ 1 & 2 & 3 & 4 & 5 & 6 & 7 \\ 1 & 2 & 3 & 4 & 5 & 6 & 7 \\ 1 & 2 & 3 & 4 & 5 & 6 & 7 \\ 1 & 2 & 3 & 4 & 5 & 6 & 7 \\ & & & & & & \\ 1 & 2 & 3 & 4 & 5 & 6 & 7 \\ 1 & 2 & 3 & 4 & 5 & 6 & 7\end{array}$

13. Los médicos deberían tratar de comprender lo que está sucediendo en la mente de los pacientes, poniendo atención a la comunicación no verbal $\mathrm{y}$ al lenguaje corporal.

14. Yo creo que las emociones no tienen lugar en el tratamiento de la enfermedad médica.

15. La empatía es una habilidad terapéutica sin la cual el éxito del médico puede estar limitado.

16. La comprensión que tenga el médico del estado emocional de su paciente, así como también de su familia, es un componente importante de la relación médico-paciente.

17. Los médicos deberían pensar como sus pacientes para poder darles un mejor cuidado.

18. Los médicos no deberían dejarse influenciar por lazos personales fuertes entre sus pacientes y los miembros de sus familias.

19. No disfruto leer literatura no médica o de arte.

20. Creo que la empatía es un importante factor terapéutico en el tratamiento médico.

\begin{tabular}{|c|c|c|c|c|}
\hline 2 & 3 & 4 & 5 & 6 \\
\hline 2 & 3 & 4 & 5 & 6 \\
\hline 2 & 3 & 4 & 5 & 6 \\
\hline 2 & 3 & 4 & 5 & 6 \\
\hline 2 & 3 & 4 & 5 & 6 \\
\hline 2 & 3 & 4 & 5 & 6 \\
\hline 2 & 3 & 4 & 5 & 6 \\
\hline 2 & 3 & 4 & 5 & 6 \\
\hline
\end{tabular}

